\title{
Evaluation of Policy Options for Expanding Oyster Aquaculture in Virginia
}

Darrell Bosch, ${ }^{1}$ Nicolai Kuminoff, ${ }^{1}$ Kurt Stephenson, ${ }^{1}$ Alex Miller, ${ }^{2}$ Jaren Pope, ${ }^{1}$ and Anna Harris ${ }^{1}$

${ }^{1}$ Department of Agricultural and Applied Economics, Virginia Tech, Blacksburg, Virginia 24061

${ }^{2}$ Gulf States Marine Fisheries Commission, Ocean Springs, Mississippi

Running title: Policy Options for Expanding Oyster Aquaculture in Virginia

Corresponding author: Darrell Bosch, Department of Agricultural and Applied Economics, Virginia Tech, Blacksburg, Virginia 24061, tel.: 540/231-5265; fax: 540/231-5265; email: bosch@vt.edu 


\title{
Evaluation of Policy Options for Expanding Oyster Aquaculture in Virginia
}

\begin{abstract}
State and Federal policymakers are considering options to increase the harvest of native oysters $(\underline{\text { Crassostrea virginica }})$ from the Chesapeake Bay and nearby coastal waters. This study investigates two policy options: reforming the current leasing system and increasing the amount of funding allocated to research and development. Analysis is based on a survey of oyster producers and an oyster bioeconomic simulation model. Results show that shellfish research aimed at increasing growth rates, reducing mortality, and reducing seed costs could significantly increase returns to oyster aquaculture. Reforming the current leasing system to expand the availability of oyster grounds would do little to increase oyster production because few growers view the current leasing system as a significant barrier to expanding their operations. Further research is needed to investigate other types of assistance to enhance oyster aquaculture and to estimate the producer response to possible price effects of expanding oyster output.
\end{abstract}

Keywords

bioeconomic model, lease, mail survey, policy, research, oyster 


\section{Evaluation of Policy Options for Expanding Oyster Aquaculture in Virginia}

Over the past century, landings for the Chesapeake Bay native oyster (Crassostrea virginica) declined by $99 \%$. In 1880 nearly 117 million pounds were harvested from the Bay, and people felt that oysters were an inexhaustible resource (Alford, 1973). By the early 1900s annual harvests had dropped to 20 million pounds, and in recent years harvests have been as low as a few hundred thousand pounds. While overharvesting played a role in this decline, parasites like Dermo (Perkinsus marinus) and MSX (Haplosporidium nelsoni), a spore-forming protozoan that infects all ages of susceptible oysters (VIMS 2005a; 2005b), are widely credited as the main factors explaining why populations have dropped over the past 50 years and have not rebounded (Alford, 1973; U.S. Army Corps of Engineers (USACE), 2008). Habitat loss is also a barrier to restoration (USACE, 2008). Oyster predators such as cow nose rays have further stymied recent restoration efforts.

Motivated by concerns over the effects of declining oyster populations on aquatic ecosystems, oyster producers, and bayside communities, state and federal policymakers are considering options for oyster restoration (Virginia Blue Ribbon Oyster Panel, 2007; USACE, 2008; Maryland Department of Natural Resources (DNR), 2007). One alternative is expansion of the oyster aquaculture industry based on either native or nonnative oyster species (USACE, 2008). Oyster aquaculture, which involves raising oysters in confined cages or floats, is an important component of a strategy to revive the industry for several reasons. First, oyster production in confined conditions can raise growth rates and reduce disease-related mortalities and predation loss when compared to traditional wild harvest or planting seed on unprotected bottoms. Second, confined production greatly reduces the need for space, thus reducing potential competition with recreation, aesthetics, and other uses of aquatic resources. Third, confined production can increase the uniformity and quality of oyster harvests, resulting in a more attractive and higher-valued product for the fresh market. 
Fourth, oyster aquaculture is the only current source of production growth in the industry, with total sales jumping from 0.85 million oysters in 2004 to 6.59 million in 2007 in Virginia and increases to 7.3 million expected for 2008 (Murray and Oesterling, 2008).

Despite this recent growth, aquaculture represents a tiny fraction of the historical oyster harvest. Compared to traditional techniques, aquaculture requires increased investment costs for oyster cages, racks, and floats and increased labor and operating costs for tending confined oysters (Lipton, 2007; Miller, 2009). Yet a variety of state and federal policies may be available to encourage the expansion and to improve the financial returns to oyster aquaculture.

The purpose of this study is to evaluate the potential effectiveness of two types of policies in stimulating oyster aquaculture production: lease reforms and research and development. The evaluation focuses on the Virginia portion of the Chesapeake Bay and nearby coastal waters and is based on information from several sources including a survey of oyster growers and an oyster bioeconomic simulation model. In the following section we describe the historical management policies for oyster grounds in the Chesapeake Bay and nearby coastal waters. We then provide background on lease reform and research and development options. Next, we describe two methods used to estimate the potential of these policy alternatives to accelerate oyster aquaculture production: an oyster grower survey and a firm-level bioeconomic simulation model. Survey and model results are described and discussed. The final section concludes with a summary and suggestions for further research.

\section{POLICY OPTIONS FOR ENHANCING OYSTER AQUACULTURE}

\section{Historical Background}

Oysters in the Maryland and Virginia areas of the Chesapeake Bay and nearby coastal waters are produced on both private and public grounds. Initially all oyster production occurred via wild harvest on public grounds. Oysters grew from the attachment of naturally 
occurring spat to bottoms made up of oyster shell or other hard substrate. Most oysters were harvested by public watermen using hand tongs. In the late $1800 \mathrm{~s}$, watermen resorted to harvest using dredging methods in order to supply the volume of oysters needed by shucking houses (Santopietro et al., 1999). Dredging methods became increasingly important and led to damage and depletion of public grounds. Scientists discovered that oyster production could be increased by restoring shell on oyster bars and replanting seed on the shell (Brooks 1891; Winslow 1881; 1894; cited in Santopietro et al, 1999). Called "shell-on-bottom" this technique required growers to occasionally deposit shell on the grounds onto which the seed could become attached and grow. This discovery brought pressure for setting aside grounds for private leasing to facilitate investments in shell placement and seed planting (Santopietro et al, 1999).

Naturally productive oyster grounds in Virginia have been reserved for public use for more than a century. In the 1890s, Lieutenant Baylor of the U.S. Navy was hired to survey all grounds and determine the naturally productive grounds. The Baylor Survey identified 250,000 acres of "Baylor grounds," which were subsequently set aside as a public fishery for watermen using hand tongs (Santopietro et al. 1999). Virginia has continually maintained this area as state managed public grounds since its creation in 1892. A second restriction was that the naturally occurring seed beds supplying seed oysters for private planters were to be reserved as a public fishery (Santopietro et al, 1999).

The Chesapeake Bay and other coastal water bottoms in Virginia not designated as part of the Baylor grounds can be leased by private interests. Virginia currently leases some 90,000 acres of bottoms (Mason 2008) in contrast to Maryland where most harvest is on public grounds. Lease rates are $\$ 1.50$ per acre per year in addition to initial surveying and registration costs, which can run as high as $\$ 600$ per plat (plot of ground) (Mason 2008). The leasing system is authorized by Virginia Code and is set up for leased areas "to be occupied 
for the purpose of planting or propagating oysters" (Chapter 6 28.2-603). This language is generally viewed as a "use it or lose it" clause in the sense that leases are granted on the condition of use in shellfish production.

To ensure that commercial oyster growers are not excluded from potentially productive grounds, Virginia has established two new policies. The first is the Oyster Lease Use Plan (2006) which requires lease holders to answer a questionnaire describing their intended use of the leased area. The questionnaire, administered by the Virginia Marine Resources Commission (VMRC), explicitly states that leases cannot be purchased for the sole purpose of preventing others from using that water for commercial oyster operations. The second new policy intends to track how leases are being used by requiring growers to report their production on privately leased grounds on a monthly basis (Mason 2008). Neither policy contains an enforcement mechanism against waterfront property owners who hold leases because of the NIMBY (not in my backyard) attitude towards working waterfronts.

In addition, Virginia oyster growers must secure a permit from the VMRC for the use of cages and floats on leased grounds. These regulatory requirements establish limitations on the density, type, location, and administrative fees for the use of oyster confinement equipment (generally see 4 VAC 20-1130). Opposition to expanding oyster aquaculture has occurred in both Virginia and Maryland due to concerns that such operations will obstruct waterfront views and other recreational water uses. Some areas of Virginia have experienced controversy between waterfront property owners and watermen who seek permits and leases to expand oyster aquaculture production (Soper, 2008).

\section{Lease and Regulatory Reform Options}

We consider three lease reform proposals aimed at increasing oyster production; 1) increasing availability of private oyster grounds; 2) amending existing lease rates and 
permitting fees, and 3) shortening the period required for obtaining approval of lease and operating permits.

\section{Increasing Private Ground Availability}

Conceptually, making private grounds more accessible to oyster aquaculturalists could increase the supply of oysters. One option would be to resurvey the Baylor grounds. A resurvey of Baylor would identify which grounds are no longer naturally productive and would then open up some of these "unproductive" grounds for private leasing. Commercial growers may be able to utilize some of these currently unproductive areas for intensive oyster aquaculture cultivation.

The geography of Virginia coastal waters including the Chesapeake Bay has changed through time due to hurricanes, changes in tides and the surrounding landscape, and gradual sea level rise (Thunberg and Shabman 1988). Grounds that were productive during the Baylor survey may be unproductive today due to lack of shell replenishment, sedimentation and other factors. Furthermore, with new Geographic Information Systems (GIS) technology, it would be possible to provide a more precise mapping of the bottoms than was conducted during the original survey. Researchers at the Virginia Institute of Marine Science (VIMS) are currently working on a GIS project to identify areas within Baylor that would best support aquaculture based on both environmental and physical conditions (VIMS, 2008). The results of their research could serve as a starting point for a new survey.

Access to private oyster grounds may also be expanded by making amendments to the existing leasing program. While the original intention of leased grounds was to "be occupied for the purpose of planting or propagating oysters," many leases are thought to be no longer actively used (Mason 2008). The current leasing system could be altered to increase utilization of bottoms for aquaculture by more strictly enforcing the "use it, or lose it" nature of the original law. Lease-holders who no longer actively perform aquaculture on their leases 
would need to start an aquaculture operation or rent the lease to shellfish producers. A challenge with this approach is defining what constitutes an adequate level of use.

\section{Lease Rates and Permit Fees}

As described above, oyster aquaculture operations must pay an annual fee for all leased bottoms. In addition to leasing rates identified above, the general permit requires minimum fees of $\$ 125$ for 500 cages and a maximum of $\$ 1,000$ for 2,500 or more cages ( 4 VAC 20-1130-60). In Virginia, float operations are assessed an impact fee of 0.5 cents per square foot of impacted habitat. Lowering the financial cost of renting grounds or obtaining permits would be a second policy reform with the potential to increase oyster production.

\section{Shortening Time Required for Regulatory Approval for Aquaculture Production}

Gaining regulatory permission to begin operations also imposes a time cost on oyster aquaculture operations. The time delay is a period that may elapse as a result of the time needed to acquire necessary leases and permits for an oyster aquaculture facility. Time costs may increase in the near future, given current opposition to oyster aquaculture expansion in some areas of Virginia. A third area for potential reform would be to formulate policy that streamlines the permitting process to avoid the costs of potential time delays.

\section{Research and Development Options}

The disease parasites Dermo (Perkinsus marinus) and MSX (Haplosporidium nelsoni) are major reasons for the decline of oyster harvests in the Chesapeake Bay (VIMS 2005a; 2005b). In response to these parasites, growers have shifted production to lower salinity grounds where the diseases are less active (Ewart and Ford 1993; Allen and Frank-Lawale 2008; Luckenbach, Francis Xavier, and Taylor 1999). However, oysters grow slower in lower salinity grounds, which lengthens growout times and exposure to predation and other disease. Oyster profits and economic potential are also restrained by the high cost of seed (Bosch and Shabman, 1990; 1989), which lowers growers' profit margins and increases their 
risk exposure. Another response has been the development of triploid seed oysters, which, because they are largely infertile, can invest more energy into growth allowing them to exceed the growth of fertile diploid oysters (Nell 2002).

Given the importance of disease and seed costs, we consider three research and development options that the state could use to increase public support and investment: 1) reducing the cost of seed by operating a state operated hatchery; 2) reducing disease susceptibility and mortality through additional disease mitigation research; and 3) increasing growth rates.

\section{METHODS}

Two methods are used to assess the efficacy of these policy alternatives to enhance oyster aquaculture production: an aquaculture operator opinion survey and a bioeconomic simulation model. In some cases, both methods are used to evaluate specific policy options. In other cases, either survey or simulation is used for evaluation, depending on the applicability of the method to the particular policy option.

\section{Oyster Grower Survey}

In March of 2008, we collaborated with the Virginia Institute of Marine Science and the University of Maryland to survey oyster and clam growers in Virginia. Using a mailing list provided by the Virginia Marine Resources Council, mail surveys were sent to 150 shellfish (oyster and clam) growers. Sixty-five responses were received, a $43 \%$ response rate. The survey, however, reflected the opinions of most of the existing aquaculture operators. Thirty respondents, representing the largest growers, represented approximately $90 \%$ of total oyster aquaculture production in Virginia. The survey asked growers to: (i) describe the size of their operations, (ii) speculate on how they would change the size of their operations in response to price changes, (iii) comment on the main factors that prevent them from expanding their 
operations, and (iv) provide feedback on some of the policy options described above. A copy of the survey is available from the authors upon request.

\section{Oyster Bioeconomic Model}

A firm-level financial simulation model was developed to analyze the costs and returns of a simulated oyster aquaculture operation (Miller, 2009). The financial simulation, which is embedded in a spreadsheet, estimates annual net returns over a 10 -year investment period and the internal rate of return (IRR) of the investment as a function of parameters describing input costs, prices, and oyster production. The internal rate of return (IRR) is the cost of capital (discount rate) which just equates the discounted stream of future net revenues to the upfront investment costs in the aquaculture operation. After presenting the structural components of the model, we describe how the parameters were calibrated to allow the model to depict a "representative" oyster grower.

Net cash flow revenue in time period t equals total revenue minus total costs.

$$
\mathrm{CF}_{\mathrm{t}}=\mathrm{TR}_{\mathrm{t}}-\mathrm{TC}_{\mathrm{t}}
$$

Total revenue equals the proportion of annual oyster production devoted to the shucked market times the price of shucked oysters plus the proportion of oyster production devoted to half shell sales times the price of half shell oysters.

$$
\mathrm{TR}_{\mathrm{t}}=\left(\left(\mathrm{O}_{\mathrm{t}}\right)\left(\%_{\text {shucked }}\right)\left(\mathrm{P}_{\text {shucked }}\right)+\left(\mathrm{O}_{\mathrm{t}}\right)\left(\%_{\text {halfshell }}\right)\left(\mathrm{P}_{\text {halfshell }}\right)\right.
$$

Annual oyster production $\left(\mathrm{O}_{\mathrm{t}}\right.$ is estimated by specifying the oyster stocking density, growout rates, and mortality rates. The total number of oysters produced for market and time to market are determined through an oyster aquaculture production function based on size at nursery entry, growout stocking rate, size at harvest, and weather and disease mortality. Typical mortality levels due to disease and predation are included in cumulative growout mortality.

Total costs are comprised of the following: 


$$
\mathrm{TC}_{\mathrm{t}}=\mathrm{TC}_{\mathrm{APt}}+\mathrm{TC}_{\mathrm{OMt}}+\mathrm{I}_{\mathrm{t}}
$$

$\mathrm{TC}_{\mathrm{APt}}$ is annual costs for administration and permitting of the operation including liability and property insurance, legal maintenance fees, permitting fees, and bottom lease fees for growout area. $\mathrm{TC}_{\mathrm{OMt}}$ is total annual costs for operation and maintenance including seed to stock the nursery or growout stage, as well as other materials needed for production and harvest. Labor costs, are incurred for nursery, growout, harvest, and marketing operations. The program requires the user to identify wage rates and estimate time required to complete tasks. $\mathrm{I}_{\mathrm{t}}$ is costs for capital investments including both initial capital outlays and replacement capital items during the investment lifetime. Initial capital investment costs include boats, oyster cages and/or floats, equipment for nursery, administrative costs, and other miscellaneous capital costs. Initial capital investment costs are incurred in the first year in the simulation model and in other years when replacement is necessary. The model estimates total cages or floats needed for production based on user supplied information concerning production targets and stocking density per cage or float.

The net present value (NPV) of the investment is the amount such that

$$
N P V=\sum_{T=0}^{n} \frac{C F_{t}}{(1+r)^{t}}
$$

where $r$ is the discount rate set equal to the firm's weighted average cost of capital and $\mathrm{n}$ represents the investment lifetime. The IRR is the discount rate which sets the NPV equal to 0 .

$$
N P V=\sum_{T=0}^{n} \frac{C F_{t}}{(1+I R R)^{t}}=0
$$

Table 1 defines the parameters that were used to specify the bioeconomic model to depict a simulated commercial oyster operation using off-bottom cage or float technology in the Chesapeake Bay region. Model parameters were defined using data from two types of sources. First, information from recently published journal articles and technical reports was 
used to define the parameters describing input costs, labor requirements, output prices, and production inputs such as growth and mortality (Murray and Oesterling 2008; Lipton, 2007; Kallen et al., 2001; Wieland, 2007; USACE, 2008). Then these parameters were verified and refined through personal discussions and on-site visits with five commercial aquaculture growers in the Chesapeake Bay. Based on these data, the simulated operation broadly reflects typical large-scale commercial oyster aquaculture operations in the Bay region. The oyster grower survey described above provided additional data on prices and production levels of commercial aquaculture operations. These costs and production levels do not describe any particular grower; they reflect the average prices and input levels reported in the literature on oyster aquaculture or that were related to us by growers.

Both the simulated float and cage operations are assumed to initially buy and rear oyster seed (1 to $4 \mathrm{~mm}$ ) in a nursery (upweller) system. The baseline assumes a seed price of $\$ 7.00$ per 1,000. Annual target production for the cage and float operations are assumed to be 1,000,000 and 500,000 oysters respectively, as cage aquaculture operations in the Chesapeake Bay tend to be of a larger scale.

Like most oyster aquaculture operations, the simulated firms market their oysters primarily to the half-shell market with $90 \%$ of all production assumed to be sold in the half shell market. Halfshell oysters can range from $\$ 0.22$ to $\$ 0.55$ per market-sized oyster, with the average halfshell prices between $\$ 0.28$ to $\$ 0.30$ (Bosch et al., 2008; Murray and Oesterling, 2008). For this simulation, the wholesale halfshell market price per oyster is $\$ 0.38$ for float operations and $\$ 0.28$ for cage operations. The float aquaculture operation is assumed to receive a higher output price because such operations typically participate in more direct marketing to retail outlets (Kallen et al., 2001). In both float and cage simulations, wage rates were assumed to be $\$ 12.00 / \mathrm{hr}$ (Lipton, 2007) and labor requirements per production tasks (unit hours sorting/stocking, growout, harvest, etc) were estimated based 
on grower discussions (see Table 1). The float operation has higher labor requirements than the cage operation, even though it is half the size, because of higher labor requirements in growout and the lower stocking rate per growout unit. Cage and float costs are based on Wieland (2007) and grower feedback.

While mortality rates can vary significantly across time and location, mortality rates for the growth cycle are $25 \%$ (float) and $30 \%$ (cage), which are largely reflective of rates reported elsewhere (Lipton, 2007). The cage operation's oyster growout time from 0.5 to 3 inches $(1.3$ to $7.6 \mathrm{~cm})$ averages 18 months, but growth rates tend to be highly variable within each production cycle. Consequently, growers typically harvest several times during a growout period. This simulation assumes $25 \%$ of oyster production for the cage operation is harvested at 16 months, $50 \%$ at 18 months, and $25 \%$ at 20 months. For the float operation the growout time from 1 to 3 inches $(2.5$ to $7.6 \mathrm{~cm})$ averages 16 months; $25 \%$ ready at 14 months, $50 \%$ at 16 months and $25 \%$ at 18 months. Several reasons for higher growth rates and lower mortality rates for float operations include better constant positioning in the water column and better fouling control (float operations tend to inspect and clean production units more often). Float operations, however, also incur higher labor costs (see Table 1).

The last two rows of Table 1 report the net present value and internal rate of return for the baseline cage and float operations. For example, the simulated cage enterprise produces an $8.4 \%$ internal rate of return and 10-year NPV of $\$ 81,900$ (assuming 5\% discount rate). The simulated float operation produces a $10.2 \%$ internal rate of return and a 10 -year NPV of $\$ 54,500$. The five aquaculture operations that we interviewed agreed that these figures are realistic.

After baseline input, costs, production, and output prices are identified, sensitivity analysis on the simulated firm's internal rate of return is performed on cost and production inputs that can be impacted by the policies described above. For example, lease rates and 
time to gain regulatory approval can be used to estimate the firm-level impact of lease policy. Similarly, incrementally changing oyster seed costs, mortality rates, and growth rates through model input provide insight into the potential impact of state investments in oyster research and development. A sensitivity index (S.I.) is created to compare the responsiveness of return on oyster aquaculture operations to changes in economic parameters (Boggess and Amerling, 1983). For example, the S.I. for seed cost is defined as:

$$
\text { S.I. }=\frac{\% \Delta I R R}{\% \Delta \operatorname{seed} \cos t}
$$

The S.I. is simply an elasticity. In this example, the S.I. can be interpreted as the elasticity of the internal rate of return to the cost of seed. All S.I.'s are calculated relative to the baseline levels of growout mortality and internal rate of return.

\section{RESULTS}

\section{Increasing Private Ground Availability}

Survey responses from active oyster growers indicated that an increase in private oyster ground availability would be unlikely to result in significant changes in oyster aquaculture production. Growers were asked about the most important factors in constraining their oyster production (See Table 2). In general growers indicated that the availability of grounds was the least important constraint, with only 4 percent of respondents (representing 10\% of total estimated production) reporting that ground availability was the most important constraint. A separate question asked growers what was the most important way state and federal agencies could assist the industry (Table 3). Oyster growers ranked enforcement of "proof of use" lease requirements as one of the least helpful actions.

On the other hand, many oyster growers did indicate that they could still benefit from opening new ground to leasing. A bare majority of oyster growers (52\%) supported opening up some current Baylor grounds for private leasing. Fewer growers (41\% of growers representing $42 \%$ of production) indicated they would lease these grounds (see Table 4). 
When asked specifically what the state could do to change the current leasing system, however, only $22 \%$ of growers (representing $12 \%$ of total production) indicated that resurveying Baylor grounds was the most important action (see Table 5)

These results suggest that additional grounds may be a marginal benefit to current growers, but lack of grounds is not a significant constraint on industry expansion. These survey results are also consistent with the fact that there still exists unused or underutilized private grounds under the current leasing program (Mason, 2008).

\section{Changing Lease Rates and Permitting Fees}

Both survey and simulation results indicate that changing the lease rates will not produce any significant financial incentives for expansion. Oyster growers indicated that a change in leasing prices would be the least effective way to improve the current leasing system (see Table 5). Likewise, the bioeconomic simulation model indicates that reducing the lease rental (currently $\$ 1.50 / \mathrm{ac} / \mathrm{yr}$ ) and the permit fees ( $\$ 625$ for operation with approximately 1500 cages) by half would have a negligible impact on the internal rate of return. For example, under current lease rates and permit fees, the typical cage enterprise has an $8.4 \%$ internal rate of return and a 10 -year discounted stream of returns of $\$ 81,900$. These figures change to $8.5 \%$ and $\$ 84,300$ when lease rates and permit fees are cut in half. Reducing the habitat impact fee by half for the float operation produces a similar negligible impact on the internal rate of return.

A lease system may be designed to achieve multiple objectives related to industry output, government revenues, and employment. Each of these components would need to be addressed in a thorough cost-benefit analysis of the current leasing system. While this is not the objective of our analysis, it is clear that cutting lease rates and permitting fees in half would have a negligible effect on employment and revenue. This is because current rates are 
quite low and so is the number of affected growers. As a result, total revenue from permitting fees and lease rates in 2007 was approximately \$23,000 (Mason 2008).

Changing Time to Approval of Lease and Operating Permit

The time and effort required to gain approval to start or expand an oyster aquaculture operation does not appear to be a major issue for most oyster aquaculture operations in Virginia. However, for the relatively small number of producers who do experience delays, the financial costs are not trival. While most oyster producers responding to the survey did not feel that the current leasing/permitting system was a major barrier to their expansion, about 1 in 5 respondents indicated that reducing time and hassle would be the most beneficial change to the current leasing system (Table 5). In response to another question, about 10 percent of oyster growers indicated that minimizing conflicts with landowners and recreational users would be the single most important way the state agencies could assist their operations (see Table 3).

To examine the financial impact of a delay in gaining approval to operate a aquaculture facility, the baseline 10-year simulation model was modified by adding one year to gain regulatory approval to operate. In the additional year, both the simulated cage and float operation incurred permitting and leasing costs as well as an opportunity cost of the operator to gain administrative approval (assumes 2 days of work per week at an opportunity cost of $\$ 30 / \mathrm{hr}$ ). This scenario is included simply to estimate the sensitivity of grower returns to a significant delay in permitting. The financial implications of a one year permit delay are shown in Table 6. The delay as described above for the simulated cage and float operation would reduce internal rate of return by $0.7 \%$ and $1.6 \%$ respectively.

\section{Changing Mortality Rates}

As an alternative to reforming the existing management program, the state could elect to devote additional resources to research and development of more disease tolerant oysters. 
Active oyster growers identified problems with disease as the second most important factor constraining the expansion of their operations (Table 2). Again, simulation results from the bioeconomic model buttress the survey results. Simulation results indicate if research and development efforts could successfully produce modest reductions in mortality, the financial returns to aquaculture could increase substantially. Our baseline simulated oyster cage operation assumes a growout mortality of $30 \%$. Lowering mortality to $25 \%$ and $20 \%$ would increase internal rates of return from $8.4 \%$ to $9.8 \%$ and $11.1 \%$ respectively (see Table 6). The sensitivity index for the change in mortality is -1.0 , meaning that one percent reduction in mortality will produce a one percent increase in the internal rate of return, all other factors constant. Furthermore, lowering mortality rates from $30 \%$ to $20 \%$ could more than double the discounted stream of net revenues over a 10 year period (see Table 6). Results are similar for the float operation.

\section{Improving Growth Rates}

State investment in research that could increase the growth rates of oysters can also have a substantial impact on the willingness to invest in new oyster aquaculture production. The initial assumption for the simulated oyster aquaculture facilities is that oyster growout averages 18 months for the cage operation and 16 months for the float operation. These assumptions were changed assuming that time to harvest was reduced by 2 months, a $11 \%$ and $12.5 \%$ increase in growth rates over the baseline, for cage and float operations, respectively.

Such improvement in oyster growth would produce relatively large increases in rates of return. For the simulated cage operation, rates of return increase from $8.4 \%$ to $13.3 \%$ (See table 6). The discounted net revenue over the 10 -year period more than doubles from $\$ 81,900$ to over $\$ 200,000$. For the float operation, the internal rate of return increases from $10.2 \%$ to 16.7\%. The sensitivity index for both the cage and float operation are both over -5.0 , 
indicating that every one percent reduction in growout time produces a 5 percent increase in rate of return (see Table 6)

\section{Changing Seed Cost and Availability}

Exactly half of all survey respondents identified the availability and cost of seed as the single most important factor limiting industry expansion (see Table 2). Oyster producers also stated that the single most important activity the state can do to assist the industry is to develop a state-supported hatchery (see Table 3).

To examine the effects of lowering seed cost, the simulated oyster seed price was reduced from $\$ 7$ to $\$ 6$ per 1,000 . This $14 \%$ drop in seed prices would raise the internal rate of return of the baseline simulated cage operation from $8.4 \%$ to $9.1 \%$. For float operations, reducing the seed price from $\$ 7$ to $\$ 6$ caused the expected 10-year internal rate of return to increase from $10.2 \%$ to $10.8 \%$ (Table 6). The S.I. for seed price of -0.4 to -0.5 indicates internal rate of return is less sensitive to seed costs compared to most other factors discussed above. These survey and simulation results suggest that it is availability rather than cost of seed, which most concerns growers.

\section{Joint Potential Impact of Research and Development}

The previous discussion suggested that research and development of faster growing, more disease tolerant oysters could have a substantial impact on the returns to oyster aquaculture. Faster growing oysters would have less exposure to disease mortality; therefore mortality rates could reasonably be expected to decline with increased growth rates. To estimate the potential joint impact, the simulation model estimated the internal rate of return from both a two month reduction in the average growout period (apporoximately $12 \%$ reduction in grow out time) and a reduction in mortality (from $30 \%$ to $25 \%$ for cage operations and $25 \%$ to $20 \%$ for float operations). 
Combined, these changes in both growth rates and mortality rates would nearly double the internal rates of return for both simulated cage and float operations. The internal rate of return increases from $8.4 \%$ to $14.8 \%$ for the cage operation and increases from $10.2 \%$ to $18.3 \%$ for the float operation. The ten-year discounted stream of net revenue increases about 3-fold, with a total net present value of $\$ 249,000$ for the cage operation and $\$ 170,100$ for the float operation. The high sensitivity of returns to growth and mortality rates helps to explain the keen industry interest in the introduction of faster growing Asian oyster species to the Chesapeake Bay (Blankenship, 2006; USACE, 2008).

\section{SUMMARY AND CONCLUSIONS}

State and Federal policymakers are investigating options to increase oyster harvests in the Chesapeake Bay and nearby coastal waters. One option being considered is to encourage oyster aquaculture operations, which produce oysters in confined cages or floats. This study investigated the potential effectiveness of lease reforms and research and development options in enhancing oyster aquaculture output. A survey of oyster producers and an oyster bioeconomic simulation model were used in evaluation of these options.

In general, changes to the existing leasing and permitting system will likely have only a marginal influence on aquaculture production. The availability of suitable lease ground is not a large barrier for expansion to oyster aquaculture. Only $12 \%$ of oyster growers identified conflicts with surrounding property owners as the most important barrier limiting expansion of their operations and only $4 \%$ listed availability of grounds as most important. Changing leasing policy on existing grounds or changing leasing and permitting fees would appear to have only a minimal impact on growers. Some conflicts between shellfish growers and surrounding landowners have been widely publicized in the local media, but such conflicts do not appear to be a systematic or widespread obstacle for the industry. A slight 
majority of active oyster producers surveyed supported opening some of the current (unproductive) Baylor grounds to leased shellfish production. Overall, this pattern of survey results suggests that reforms to the state's current leasing policy aimed at increasing availability of grounds appear unlikely to encourage significant new production.

Both survey and simulation results suggest that the significant challenges and opportunities for the oyster industry are related to issues of oyster growth, oyster mortality, and oyster seed availability. Publicly-sponsored shellfish research has the potential to significantly benefit the oyster industry. Both the oyster grower survey and the bioeconomic model provide strong support for the importance of enhancing growth rates and reducing mortality rates. Bioeconomic simulation results suggest that oyster net revenues are most sensitive to changes in oyster growout time followed by changes in oyster mortality and seed price. Simulation results provide strong evidence of the high potential returns to the oyster industry from research that could provide even modest improvements in oyster growth rates such as providing wider access to triploid seed.

This analysis is short-run and does not consider any price responses to increasing oyster supplies. If research results were adopted widely, oyster supplies might increase sufficiently that prices would fall and negate some of the benefits to producers of the increased production efficiency. Of course, these results are also contingent on the ability of additional research and development efforts to actually produce improvements in growth and mortality rates.

Further research is needed to investigate other types of assistance to enhance oyster aquaculture. Previous research suggests that the financial returns to an oyster aquaculture operation are sensitive to relatively small changes in oyster prices (Miller, 2009; Lipton, 2007). Any marketing or other activities that add value to production will have an immediate and significant impact on oyster aquaculture investment. One potential way to add value to 
production is through the creation of additional revenue streams. Oysters provide water quality benefits through nutrient assimilation. Payments for such services could provide a ‘win-win' opportunity, which enhances water quality and contributes to oyster net returns (Newell, 2004; Shabman and Stephenson, 2007; Kuminoff et al., 2008; Miller, 2009). However, the magnitude of improvements to water quality and to oyster growers' net returns need to be quantified to determine if this option merits further consideration by policymakers.

\section{Acknowledgements}

Partial funding support was provided by the Coastal Zone Management program of the National Oceanic and Aeronautics Administration, grant number \#NA07NOS4190178 and the targeted watershed grant program of the Environmental Protection Agency/National Fish and Wildlife Foundation. The authors express appreciation to Vijay Satyal for his assistance and encouragement and the input and assistance from Virginia and Maryland oyster growers.

\section{References}

Alford, John (1973) The role of management in Chesapeake Bay oyster production. Geographical Review 63( 1), 10.

Allen, Jr., S.K., \& A. Frank-Lawale (2008) Triploid 3n advantage. Gloucester Point, Virginia: Virginia Institute of Marine Science.

Blankenship, Karl (2006) Asian, native oysters go head-to-head in Bay. Bay Journal January. [Cited January 29 2009] http://www.bayjournal.com/article.cfm?article=2704.

Boggess, W. G. \& C. B. Amerling (1983) A bioeconomic simulation analysis of irrigation investments. Southern Journal of Agricultural Economics 15, 135-142.

Bosch, Darrell, Nicolai V. Kuminoff, Anna Harris, Jaren C. Pope, Kurt Stephenson, \& Pam Mason (2008) Economic Implications of Alternative Management Strategies for 
Virginia Oysters and Clams. Final project completion report. Richmond, Virginia: Virginia Department of Environmental Quality, Coastal Zone Management Program. $116 \mathrm{pp}$.

Bosch, Darrell J. \& Leonard A. Shabman (1990) Simulation modeling to set priorities for research on oyster production. American Journal of Agricultural Economics 72(2), $371-381$.

Bosch, Darrell J. \& Leonard A. Shabman (1989) The decline of private sector oyster culture in Virginia: Causes and remedial policies. Marine Resource Economics 6(3), 227-243.

Brooks, William (1891) The Oyster. Baltimore: Johns Hopkins U. Press.

Ewart, John W., \& Susan E. Ford (1993) History and impact of MSX and Dermo diseases on oyster stocks in the Northeast Region. North Dartmouth Massachusetts Northeastern Regional Aquaculture Center, University of Massachusetts Dartmouth.

Kallen, R., K. Morse, D. Grosse, and D. Leonard (2001) Small-scale oyster farming for Chesapeake watermen-A sustainable business marketing plan. Towson, MD: TerraAqua Environmental Science and Policy, LLC. Prepared for the Campbell Foundation for the Environment.

Kuminoff, Nicolai V., Darrell J. Bosch, Dan Kauffman, Jaren C. Pope, and Kurt Stephenson. (2008) The growing supply of ecolabeled seafood: An economic perspective." Sustainable Development Law and Policy (9:1) Fall.

Lipton, D. (2007) Economic Assessment of Aquaculture Alternatives to Restore Chesapeake Bay’s Oyster Population. College Park, MD University of Maryland College Park.

Luckenbach, M. W., O. Francis Xavier, \& J. Taylor (1999) An introduction to culturing oysters in Virginia. Gloucester Point, Virginia: Virginia Institute of Marine Science, College of William \& Mary. 
Maryland Department of Natural Resources (DNR) (2007) "Maryland Establishes New Oyster Advisory Commission." [cited February 9, 2009] Southern Maryland Online. http://somd.com/news/headlines/2007/6398.shtml.

Mason, P. (2008) Identification of management strategies for promoting aquaculture in Virginia. Report to the Virginia Coastal Zone Management Program. Gloucester Point, Virginia: Virginia Institute of Marine Sciences.

Miller, Alex (2009) An Economic Evaluation of the Nutrient Assimilation Potential for Commercial Oyster Aquaculture in the Chesapeake Bay.. M.S. thesis, Department of Agricultural and Applied Economics. Virginia Tech.

Murray, T. \& M. J. Oesterling (2008) Virginia shellfish aquaculture, situation, and outlook report: Results of Virginia shellfish aquaculture crop reporting survey 2005-2007. Gloucester, Virginia: Virginia Institute of Marine Science.

Nell, J. A. (2002) Farming Triploid oysters. Aquaculture 210(1-4), 69-88.

Newell, R. (2004). Ecosystem influences of natural and cultivated populations of suspension feeding bivalve molluscs: A review. Journal of Shellfish Research (23): 51-61.

Santopietro, G., L. Shabman, \& K. Stephenson (1999) The common good in oysters. Selected paper presented at the International Society for New Institutional Economics. Blacksburg, Virginia: Virginia Tech.

Shabman, L. and K. Stephenson (2007) Achieving Nutrient Water Quality Goals: Bringing Market-like Principles to Water Quality Management. Journal of the American Water Resources Association (43,4): 1076-1089.

Soper, Shawn (2008) Panel to study expanding aquaculture in coastal bays. The Dispatch. June 20, 2008. [Cited September 12th 2008]. Available from http://www.mdcoastdispatch.com/article.php? cid=30\&id=3657 
Thunberg, E. and L. Shabman. (1988) An evaluation of alternative strategies for Virginia oyster grounds management: economic considerations in policy design. Virginia Agricultural Experiment Station. VSG-88-03: 105 pp.

U.S. Army Corps of Engineers (USACE) (2008) Draft programmatic environmental impact statement for oyster restoration in Chesapeake Bay including the use of a native and/or nonnative oyster. Corps of Engineers, Norfolk District. Volumes 1 and 2. Available at http://www.nao.usace.army.mil/OysterEIS/EIS/homepage.asp

Virginia Blue Ribbon Oyster Panel. (2007) Report and Recommendations of the Blue Ribbon Oyster Panel. [cited February 9, 2009] Online at: http://noaa.chesapeakebay.net/docs/FinalReport2007.pdf

VIMS (Virginia Institute of Marine Sciences) C. f. C. R. M. (2008) Assessment of aquaculture potential within Baylor grounds in the Lower Rappahannock River. Gloucester Point, Virginia.

VIMS (Virginia Institute of Marine Sciences) (2005a) Oyster diseases of the Chesapeake Bay Dermo fact sheet 2005. [cited May 2, 2008]. Gloucester Point, Virginia. Available from http://www.vims.edu/env/research/shellfish/dermo.html.

VIMS (Virginia Institute of Marine Sciences) (2005b) Oyster diseases of the Chesapeake Bay MSX fact sheet 2005 [cited May 2 2008]. Gloucester Point, Virginia. Available from http://www.vims.edu/env/research/shellfish/msx.html.

Wieland, R. (2007) Costs and Returns to Oyster Aquaculture In the Chesapeake Bay. Main Street Economics, Trappe, Maryland. Prepared for the NOAA Chesapeake Bay Program Office Non-Native Oyster Research Program.

Winslow, Lieut. F. (1881) Deterioration of American oyster beds. The Popular Science Monthly 20:29-43. 
Winslow, Lieut. F. (1894) Speech in proceedings of the conventions called to consider and discuss the oyster question. Richmond, Va.: J.W. Fergusson and Sons, Printers. 
Table 1 Baseline Parameters Used to Define a Simulated Aquaculture Enterprise

\begin{tabular}{|c|c|c|}
\hline Parameters & Cage & Float \\
\hline Annual baseline production target & $1,000,000$ & 500,000 \\
\hline Growout stocking density per cage or float & $\begin{array}{l}5,000 \text { (nursery) } \\
1,500 \text { (growout) }\end{array}$ & 1,000 \\
\hline Cost per cage or float & $\begin{array}{l}\$ 250 \text { (nursery) } \\
\$ 225 \text { (growout) }\end{array}$ & $\$ 125$ \\
\hline Seed cost $(\$ / 1000)$ & $\$ 7$ & $\$ 7$ \\
\hline Number of cages/floats used & 1,579 & 711 \\
\hline Labor cost per hour & $\$ 12$ & $\$ 12$ \\
\hline Annual labor requirement (hours) & 4,225 & 5,075 \\
\hline Cumulative growout mortality rate & $30 \%$ & $25 \%$ \\
\hline $\begin{array}{l}\text { Total number of months to market for first } 25 \% \text { of } \\
\text { harvest }\end{array}$ & 16 & 14 \\
\hline Total number of months to market for middle $50 \%$ & 18 & 16 \\
\hline Total number of months to market for final $25 \%$ & 20 & 18 \\
\hline Size entering growout production stage & 1 inch $(2.5 \mathrm{~cm})$ & 0.5 inch $(1.3 \mathrm{~cm})$ \\
\hline Size leaving growout production stage & 3 inches $(7.5 \mathrm{~cm})$ & 3 inches $(7.5 \mathrm{~cm})$ \\
\hline Percent $(\%)$ of oysters to halfshell market & $90 \%$ & $90 \%$ \\
\hline Percent $(\%)$ of oysters to shucked market & $10 \%$ & $10 \%$ \\
\hline Half-shell oyster market prices per oyster & $\$ .28$ & $\$ .38$ \\
\hline Shucked oyster market prices per oyster & $\$ .14$ & $\$ .14$ \\
\hline Net present value (NPV) & $\$ 81,900$ & $\$ 54,500$ \\
\hline Internal rate of return (IRR) & $8.4 \%$ & $10.2 \%$ \\
\hline
\end{tabular}


Table 2 What Factors Constrain Your Ability to Expand Your Current Oyster Production? (1 for Most important, 2 for Second Most Important, etc)

\begin{tabular}{lccc}
\hline & & & $\begin{array}{l}\text { \% of Growers } \\
\text { Who Rank as \#1 } \\
\text { (Weighted by }\end{array}$ \\
Problem & Who Rank as \#1 & $\begin{array}{l}\text { Mean Ranking } \\
\text { Over all Growers }\end{array}$ & $\begin{array}{l}\text { Production) } \\
\text { Prower }\end{array}$ \\
\hline Availability/cost of seed & 50 & 2.1 & 53 \\
$\begin{array}{l}\text { Availability of grounds } \\
\text { Lack of market/low price }\end{array}$ & 4 & 4 & 10 \\
$\begin{array}{l}\text { Problem with predators (rays, } \\
\text { crabs, etc.) }\end{array}$ & 19 & 3.43 & 3 \\
$\begin{array}{l}\text { Problems with disease } \\
\text { (MSX, Dermo) }\end{array}$ & 4 & 3.6 & 13 \\
$\begin{array}{l}\text { Permitting issues/land use } \\
\text { conflict }\end{array}$ & 12 & 2.95 & 1 \\
\hline
\end{tabular}


Table 3 What Assistance Can State Agencies and NOAA (A Federal Agency) Provide? (1 for Best Assistance, 2 for Second Best Assistance, Etc.)

\begin{tabular}{|c|c|c|c|}
\hline Type of Assistance & $\begin{array}{l}\% \text { of Growers } \\
\text { Who Rank as } \\
\# 1\end{array}$ & $\begin{array}{l}\text { Mean Ranking } \\
\text { Over all } \\
\text { Growers }\end{array}$ & $\begin{array}{l}\text { \% of Growers } \\
\text { Who Rank as } \\
\# 1 \text { (Weighted } \\
\text { by Production) }\end{array}$ \\
\hline $\begin{array}{l}\text { Assist with marketing and the } \\
\text { development of value added products }\end{array}$ & 16 & 3.48 & 5 \\
\hline $\begin{array}{l}\text { Assist in minimizing conflicts with } \\
\text { surrounding landowners and } \\
\text { recreational users }\end{array}$ & 9 & 3.55 & 5 \\
\hline $\begin{array}{l}\text { Fund research and demonstration } \\
\text { projects targeting defined industry } \\
\text { problems }\end{array}$ & 9 & 3.77 & 5 \\
\hline $\begin{array}{l}\text { Enforce 'proof of use' requirements } \\
\text { to ensure that leased grounds are } \\
\text { being used for oyster production }\end{array}$ & 6 & 4.57 & 2 \\
\hline $\begin{array}{l}\text { Assist with seed production by aiding } \\
\text { the development of hatcheries }\end{array}$ & 38 & 2.61 & 64 \\
\hline $\begin{array}{l}\text { Support educational programs for } \\
\text { technical training and extension } \\
\text { programs }\end{array}$ & 0 & 4.6 & 0 \\
\hline Protect and enhance water quality & 22 & 2.79 & 9 \\
\hline
\end{tabular}


Table 4: Support and Use of Resurveyed Baylor Grounds

\begin{tabular}{lccc}
\hline & \multicolumn{2}{c}{ Percent of respondents* } \\
& Yes & No & Don't know \\
\hline Would you support opening some Baylor & $52 \%$ & $30 \%$ & $19 \%$ \\
grounds for private shellfish aquaculture? & $(63 \%)$ & $(10 \%)$ & $(17 \%)$ \\
$\begin{array}{l}\text { If some Baylor grounds were open for private } \\
\text { use, would you lease? }\end{array}$ & $41 \%$ & $33 \%$ & $(8 \%)$ \\
\hline $\begin{array}{l}* \text { The } \% \text { of current oyster aquaculture production of respondents in each category is show in } \\
\text { parentheses }\end{array}$
\end{tabular}


Table 5 What Could State Agencies Do to Improve the Current Leasing System? (1 for Best Assistance, 2 for Second Best Assistance, Etc.)

\begin{tabular}{|c|c|c|c|}
\hline Proposed Action & $\begin{array}{l}\% \text { of Growers } \\
\text { Who Rank as } \\
\# 1\end{array}$ & $\begin{array}{l}\text { Mean Ranking } \\
\text { Over all } \\
\text { Growers }\end{array}$ & $\begin{array}{l}\% \text { of Growers } \\
\text { Who Rank as } \\
\# 1 \text { (Weighted } \\
\text { by Production) }\end{array}$ \\
\hline $\begin{array}{l}\text { Enforce 'proof of use' requirements } \\
\text { on leased bottoms }\end{array}$ & 30 & 2.21 & 17 \\
\hline Increase the lease price & 9 & 3.93 & 2 \\
\hline Lower the lease price & 0 & 3.64 & 0 \\
\hline $\begin{array}{l}\text { Reduce the time and hassle of } \\
\text { changing or acquiring leases }\end{array}$ & 22 & 2.25 & 3 \\
\hline $\begin{array}{l}\text { Open up the Baylor grounds for } \\
\text { private leases }\end{array}$ & 22 & 2.36 & 12 \\
\hline Other (please specify) & $17 *$ & 1 & 40 \\
\hline
\end{tabular}


Table 6: Influence of Policy Induced Changes on Simulated Firm Level Returns

\begin{tabular}{|c|c|c|c|c|c|c|}
\hline & \multicolumn{3}{|c|}{ Simulated Cage Aquaculture Enterprise } & \multicolumn{3}{|c|}{ Simulated Float Aquaculture Enterprise } \\
\hline & Return & Value & & & & \\
\hline Baseline & $8.4 \%$ & $\$ 81,900$ & N/A & $10.2 \%$ & $\$ 54,500$ & N/A \\
\hline $50 \%$ reduction in leasing/permit fees & $8.5 \%$ & $\$ 84,300$ & -0.025 & $10.3 \%$ & $\$ 55,100$ & -0.02 \\
\hline \multicolumn{7}{|l|}{ Reduction in mortality rates } \\
\hline Reduce mortality to $25 \%$ & $9.8 \%$ & $\$ 122,300$ & -1.0 & N/A & N/A & N/A \\
\hline Reduce mortality to $20 \%$ & $11.1 \%$ & $\$ 162,800$ & -0.96 & $11.9 \%$ & $\$ 75,100$ & -0.83 \\
\hline Combined reduction in mortality (from 30 & $14.8 \%$ & $\$ 249,000$ & N/A & $18.3 \%$ & $\$ 170,100$ & N/A \\
\hline to $25 \%$ for cage and 25 to $20 \%$ for float) & & & & & & \\
\hline and 2-month reduction in growout period & & & & & & \\
\hline
\end{tabular}

